\section{Physical and Chemical Attributes of Pomegranate (Punica granatum L.) Cultivars Grown in Humid Conditions in Georgia}

\author{
Juan C. Díaz-Pérez ${ }^{1}$ and Dan MacLean \\ Department of Horticulture, University of Georgia, 2360 Rainwater Road, \\ Tifton, GA 31793-5766
}

Smiljana Goreta

Institute of Agriculture and Tourism, Karla Huguesa 8, 52440 Poreč, Croatia

Sarah Workman

Center for Agribusiness and Economic Development, University of Georgia, Athens, GA 30602-7509

Erick Smith, Harwinder Singh Sidhu, Gunawati Gunawan, Anthony Bateman, and Jesús Bautista

Department of Horticulture, University of Georgia, 2360 Rainwater Road, Tifton, GA 31793-5766

William Lovett

University of Georgia Extension Service, Bacon County, Alma, GA 31510

\begin{abstract}
Maja Jukić Špika, Gvozden Dumičić, and Mira Radunić
Institute of Adriatic Crops and Karst Reclamation, Put Duilova 11, 21000 Split, Croatia
\end{abstract}

Additional index words. pomegranate, postharvest, fruit quality, antioxidants, Mediterranean crop

Abstract. Pomegranate (Punica granatum L.) is a nonclimacteric fruit sold fresh as whole fruit or arils (fleshy seeds). It is also used for the production of juice, wine, and syrup. Pomegranate is popular due to its numerous health benefits. In the United States, it is grown primarily in California and other semi-arid regions, with Wonderful being the most widely grown cultivar. However, preliminary research has shown that 'Wonderful' produces low yields in Georgia, thus indicating the need to identify cultivars better suited for warm and humid conditions, such as those of the southeastern United States. The objective of this study was to determine the physical and chemical quality attributes of pomegranate cultivars grown in Georgia. Pomegranate fruit from 40 cultivars were harvested during 2012 to 2017. Individual fruit weight varied from $124 \mathrm{~g}$ for 'Utah Sweet' to $631 \mathrm{~g}$ for ' $\mathrm{C1}$ '. The total fruit weight percentage accounted for by fresh aril weight (aril fraction) ranged from $22 \%$ for ' $\mathrm{C8}$ ' to $\mathbf{7 0} \%$ for ' $\mathrm{JC}$ '. Individual aril weight ranged from $174 \mathrm{mg}$ for 'Utah Sweet' to $638 \mathrm{mg}$ for 'Cloud'. Across cultivars, individual fruit weight increased linearly with the increasing number of arils. Aril color varied from white to deep red. The arils $L^{*}$ value ranged from 15.7 (dark arils) for 'Crown Jewel' to 46.1 (light arils) for 'Utah Sweet'. The $a^{*}$ values ranged from 0.6 (white arils) for 'Cloud' to 20.5 (red arils) for 'Crab'. The $b$ * values ranged from 8.7 for 'DJ Forry' (from a store) to 62.5 for 'R9'. The Chroma* values ranged from 13.4 for 'Cloud' to 24.3 for 'Crab'. The hue ${ }^{\circ}$ values ranged from 29.7 for 'Wonderful' (from a store) to 87.1 for 'Cloud'. Rind color was related to the color of the arils; high a* values in the rind and arils were associated with the red color. The fruit juice content ranged from $174 \mathrm{~mL} \cdot \mathrm{kg}^{-1}$ fruit for 'Utah Sweet' to $638 \mathrm{~mL} \cdot \mathrm{kg}^{-1}$ fruit for 'Cloud'. Cultivars varied from tart to sweet. The fruit soluble solids concentration (SSC) ranged from $\mathbf{1 0 . 8 \%}$ for 'Sin Pepe' to $\mathbf{1 6 . 4 \%}$ for 'Crown Jewel'. Fruit titratable acid (TA) ranged from $0.27 \%$ for 'Sin Pepe' to $6.20 \%$ for 'Utah Sweet'. The juice maturity index measured as the SSC/TA ratio ranged from 1.9 for 'Utah Sweet' to 39.5 for 'Sin Pepe'. The juice total phenols (measured as gallic acid equivalents) ranged from $463 \mathrm{mg} \cdot \mathrm{L}^{-1}$ for ' $\mathrm{JC}$ ' to 2468 mg. $\mathrm{L}^{-1}$ for 'Wonderful' (Georgia). Trolox equivalent antioxidant capacity values of juice ranged from 10,001 $\mu M$ for 'King' to 59,821 $\mu M$ for 'I11'. Cupric reducing antioxidant capacity values in juice ranged from $7471 \mu \mathrm{M}$ for 'Azadi' to $20,576 \mu \mathrm{M}$ for 'Wonderful' (Georgia). Juice total anthocyanins varied from $1.7 \mathrm{mg} \cdot \mathrm{L}^{-1}$ for ' $\mathrm{R} 19$ ' to $50.0 \mathrm{mg} \cdot \mathrm{L}^{-1}$ for 'Wonderful' (Georgia). Pomegranate cultivars showed large variability in physical and chemical attributes. Such pomegranate variability represents opportunities for breeding, for the retail market, and for the development of different products by the food industry.
Pomegranate is a nonclimacteric fruit consumed fresh as whole fruit or arils. It can also be used for the production of juice, wine, and syrup. Pomegranate fruit has a hard or leathery pericarp (rind) that may be red, purple, pink, or yellow (Stover and Mercure, 2007). The fruit has numerous seeds, and each seed is covered by fleshy pulp; this fleshy seed is known as an aril. Botanically, the fruit is a berry, and its seeds are produced from the ovary of a single flower. Inside the fruit, arils are attached to a white spongy mesocarp (Holland et al., 2009; Preece and Moersfelder, 2016; Stover and Mercure, 2007). Pomegranate is popular due to its health benefits, such as its anticancer and antidiabetic properties (Borochov-Neori et al., 2011; Katz et al., 2007; Matityahu et al., 2014). In the United States, pomegranate is grown primarily in California, with 'Wonderful' being the most widely grown cultivar (Holland et al., 2009). Pomegranate may be a suitable new crop for the fresh market or for processing in various southeastern states, such as Georgia and Florida. Currently, Georgia is a major producer of blueberries (Vaccinium spp.) (2016 Farm gate value report), and blueberry growers have an interest in pomegranate juice as well as blueberry juice (personal communication with growers). In 2017 and 2018, freeze events reduced blueberry production in Georgia, further increasing the growers' interest in alternative crops such as pomegranate.

Preliminary research has shown that 'Wonderful' produces low yields in Georgia, thereby indicating the need to identify pomegranate cultivars better suited for warm and humid conditions such as those of the southeastern United States. However, there is limited information regarding pomegranate cultivars and production in the southeast United States. The objective of this study was to determine the physical and chemical quality attributes of pomegranate cultivars grown in Georgia.

\section{Materials and Methods}

Pomegranate fruit of 40 cultivars were collected from at least one of three planting sites in southern Georgia (Table 1). These sites were as follows: Tifton Campus Pomegranate Farm, University of Georgia, Tifton, GA (lat. $31^{\circ} 28^{\prime} 38^{\prime \prime} \mathrm{N}$, long. $83^{\circ} 31^{\prime} 21^{\prime \prime} \mathrm{W}$; planted in 2010); Ponder Farm, University of Georgia, Ty Ty, GA (lat. 31 $31^{\prime} 40^{\prime \prime} \mathrm{N}$, long. $83^{\circ} 30^{\prime} 29^{\prime \prime} \mathrm{W}$; planted in 1990); and a commercial orchard at Don Wade Farm, Alma, GA (lat. $31^{\circ} 26^{\prime} 10^{\prime \prime} \mathrm{N}$, long. $82^{\circ} 22^{\circ} 19^{\prime \prime} \mathrm{W}$; planted in 2010). Fruit were obtained from yearly harvests during September and October from 2012 to 2017. Immediately after harvest, pomegranate fruit were transported to the Vidalia Onion Research Laboratory and stored at $5{ }^{\circ} \mathrm{C}(90 \%$ to $95 \% \mathrm{RH})$ for 1 to $3 \mathrm{~d}$ before measurements. As references, 'Wonderful' and 'DJ Forry' fruit from California (obtained from a local store in Tifton) were included in the evaluations. Fruit sample size per cultivar per farm per year varied (average of six), but it consisted of at least three fruit free from physical damage and decay. 
Breeding, Cultivars, Rootstocks, and Germplasm Resources

Table 1. Pomegranate cultivars and locations where they were grown in Georgia.

\begin{tabular}{|c|c|c|c|}
\hline Cultivar & $\mathrm{Alma}^{\mathrm{z}}$ & Tifton $^{y}$ & $\mathrm{Ty} \mathrm{Ty}^{\mathrm{x}}$ \\
\hline Afganski (R26) & $++^{w}$ & + & + \\
\hline Al sirin-nar (R6) & & + & \\
\hline Azadi & & + & \\
\hline Bala Miursal (R25) & + & + & + \\
\hline Barskislatki (C5) & & + & \\
\hline Ciparski (C8) & + & + & \\
\hline Cloud & & & + \\
\hline Crab & & + & + \\
\hline Cranberry & & + & + \\
\hline Crown Jewel & & + & \\
\hline Domaci kiseli (C6) & & + & \\
\hline Don Sumner North (DSN) & & + & + \\
\hline Don Sumner South (DSS) & & + & + \\
\hline $\begin{array}{c}\text { Dorosht } 5 \text { hahanshahi } \\
\text { Khoramabad (I7) }\end{array}$ & & & + \\
\hline Entek habi saveh (I8) & & & + \\
\hline Eve & & & + \\
\hline Fleshman & & & + \\
\hline Gissarskii Rozovyi (C1) & & + & \\
\hline Granada & & + & + \\
\hline $\mathrm{JC}$ & + & & \\
\hline Jimmy & + & & \\
\hline Kaj-acik-anor (R9) & & + & + \\
\hline King & & & + \\
\hline Lester & + & + & \\
\hline Medovyi Vahsha & & + & \\
\hline Mejhos (R2) & & + & + \\
\hline Nikitski ranni (R19) & + & + & + \\
\hline Pink & & & + \\
\hline Rose & & & + \\
\hline Sakerdze (R5) & & + & \\
\hline Salavatski (R8) & & + & + \\
\hline $\begin{array}{l}\text { Shirin Pust Ghermez } \\
\text { Saveh (I11) }\end{array}$ & & & + \\
\hline Sin Pepe & & + & \\
\hline Sirenevy & & + & \\
\hline Surh-anor (R33) & + & + & \\
\hline Sweet & & & + \\
\hline Thomson & & & + \\
\hline Utah Sweet & & & + \\
\hline Wonderful & & + & \\
\hline
\end{tabular}

${ }^{\mathrm{z}}$ Don Wade Farm, Alma, GA. Planted in 2010.

${ }^{\mathrm{y}}$ Tifton Campus Pomegranate Farm, University of Georgia, Tifton, GA. Planted in 2010.

${ }^{\mathrm{x}}$ Ponder Farm, University of Georgia, Ty Ty, GA. Planted in 1990

"The symbol "+" indicates that the cultivar was planted in the location.

Physical attributes. Individual fruit weight and diameter were determined. Fruit were peeled to determine the rind and aril weights, and their respective weight fractions (relative to total fruit weight) were calculated. For each fruit, a sample of 50 arils was weighed and the mean aril weight was determined. A

Received for publication 14 Dec. 2018. Accepted for publication 12 Mar. 2019.

We appreciate the thorough review of the manuscript by Patrick Conner, Savithri Nambeesan, and the anonymous reviewers. We thank the USDA for the financial support through the Croatia Agriculture Research and Educational Exchange grant (grant number: USDA 2009-51160-05465). We appreciate Mr. Don Wade from Alma, GA, and the Georgia Pomegranate Association for the donation of pomegranate fruit. We thank the Georgia Agricultural Experiment Stations for financial support.

${ }^{1}$ Corresponding author. E-mail: jcdiaz@uga.edu.

Table 2. Physical attributes of pomegranate fruit cultivars grown in Georgia. ${ }^{\mathrm{z}}$

\begin{tabular}{|c|c|c|c|c|c|c|}
\hline Cultivar $^{y}$ & Fruit wt $(\mathrm{g})$ & $\begin{array}{c}\text { Fruit } \\
\text { diam }(\mathrm{cm})\end{array}$ & $\begin{array}{c}\text { Rind } \\
\text { fraction }(\%)\end{array}$ & Aril fraction (\%) & $\begin{array}{c}\text { Aril } \\
\text { wt (mg/aril) }\end{array}$ & $\begin{array}{l}\text { Aril no. } \\
\text { per fruit }\end{array}$ \\
\hline$\overline{\text { Azadi }}$ & $401 \pm 23$ & $9.4 \pm 0.3$ & $44 \pm 1.4$ & $56 \pm 1.4$ & $351 \pm 9$ & $638 \pm 39$ \\
\hline $\mathrm{C} 1$ & $631 \pm 108$ & $11.0 \pm 0.7$ & $58 \pm 3.0$ & $42 \pm 3.0$ & $466 \pm 24$ & $527 \pm 65$ \\
\hline C5 & $306 \pm 27$ & $9.0 \pm 0.3$ & $50 \pm 3.9$ & $50 \pm 3.9$ & $445 \pm 14$ & $358 \pm 50$ \\
\hline C6 & $359 \pm 29$ & $9.3 \pm 0.3$ & $62 \pm 4.5$ & $38 \pm 4.5$ & $360 \pm 7$ & $391 \pm 63$ \\
\hline C8 & $312 \pm 30$ & $8.6 \pm 0.4$ & $78 \pm 5.1$ & $22 \pm 5.1$ & $433 \pm 20$ & $149 \pm 32$ \\
\hline Cloud & $299 \pm 23$ & $7.4 \pm 0.7$ & $40 \pm 2.2$ & $60 \pm 2.2$ & $638 \pm 30$ & $289 \pm 21$ \\
\hline Crab & $204 \pm 14$ & $7.8 \pm 0.1$ & $56 \pm 1.0$ & $44 \pm 1.0$ & $468 \pm 15$ & $213 \pm 27$ \\
\hline Cranberry & $365 \pm 16$ & $8.7 \pm 0.2$ & $51 \pm 0.9$ & $49 \pm 0.9$ & $523 \pm 12$ & $346 \pm 16$ \\
\hline Crown Jewel & $539 \pm 1$ & $11.3 \pm 0.5$ & $44 \pm 2.2$ & $56 \pm 2.2$ & $393 \pm 16$ & $773 \pm 29$ \\
\hline DJ Forry ${ }_{s}{ }^{x}$ & $305 \pm 35$ & $8.7 \pm 0.4$ & $51 \pm 1.1$ & $49 \pm 1.1$ & $310 \pm 5$ & $466 \pm 45$ \\
\hline DSN & $288 \pm 40$ & $7.4 \pm 0.6$ & $49 \pm 2.9$ & $51 \pm 2.9$ & $368 \pm 11$ & $415 \pm 70$ \\
\hline DSS & $332 \pm 18$ & $7.5 \pm 0.4$ & $44 \pm 1.6$ & $56 \pm 1.6$ & $310 \pm 18$ & $632 \pm 72$ \\
\hline Eve & $247 \pm 25$ & $6.3 \pm 0.3$ & $51 \pm 2.0$ & $49 \pm 2.0$ & $508 \pm 16$ & $255 \pm 36$ \\
\hline Fleshman & $244 \pm 15$ & $6.7 \pm 0.1$ & $43 \pm 1.0$ & $57 \pm 1.0$ & $386 \pm 6$ & $374 \pm 30$ \\
\hline Gissarsk & $289 \pm 24$ & $8.3 \pm 0.3$ & $55 \pm 4.1$ & $45 \pm 4.1$ & $414 \pm 18$ & $336 \pm 53$ \\
\hline Granada & $396 \pm 26$ & $8.8 \pm 0.3$ & $55 \pm 3.8$ & $45 \pm 3.8$ & $369 \pm 14$ & $514 \pm 59$ \\
\hline I11 & $290 \pm 5$ & $8.3 \pm 0.0$ & $70 \pm 3.8$ & $30 \pm 3.8$ & $354 \pm 13$ & $245 \pm 27$ \\
\hline I7 & $343 \pm 30$ & $8.6 \pm 0.3$ & $49 \pm 2.3$ & $51 \pm 2.3$ & $375 \pm 11$ & $467 \pm 46$ \\
\hline I8 & $270 \pm 9$ & $6.6 \pm 0.3$ & $47 \pm 1.3$ & $53 \pm 1.3$ & $325 \pm 7$ & $446 \pm 19$ \\
\hline $\mathrm{JC}$ & $242 \pm 8$ & & $28 \pm 0.1$ & $70 \pm 0.1$ & $347 \pm 2$ & $487 \pm 15$ \\
\hline Jimmy & $402 \pm 3$ & & $30 \pm 0.4$ & $69 \pm 0.4$ & $347 \pm 3$ & $797 \pm 5$ \\
\hline King & $300 \pm 11$ & $6.9 \pm 0.2$ & $42 \pm 2.5$ & $58 \pm 2.5$ & $385 \pm 20$ & $451 \pm 17$ \\
\hline Lester & $370 \pm 8$ & $9.0 \pm 0.2$ & $36 \pm 1.9$ & $63 \pm 1.8$ & $342 \pm 5$ & $692 \pm 28$ \\
\hline Medovyi & $269 \pm 18$ & $8.2 \pm 0.2$ & $68 \pm 5.4$ & $32 \pm 5.4$ & $424 \pm 13$ & $209 \pm 38$ \\
\hline Pink & $294 \pm 43$ & $7.5 \pm 0.4$ & $39 \pm 1.2$ & $61 \pm 1.2$ & $408 \pm 25$ & $528 \pm 108$ \\
\hline R2 & $231 \pm 9$ & $6.6 \pm 0.2$ & $55 \pm 1.5$ & $45 \pm 1.5$ & $367 \pm 13$ & $305 \pm 25$ \\
\hline R5 & $328 \pm 43$ & $9.1 \pm 0.5$ & $65 \pm 2.9$ & $35 \pm 2.9$ & $406 \pm 28$ & $290 \pm 54$ \\
\hline R6 & $280 \pm 13$ & $8.3 \pm 0.2$ & $37 \pm 2.6$ & $63 \pm 2.5$ & $482 \pm 10$ & $367 \pm 19$ \\
\hline R8 & $319 \pm 13$ & $8.5 \pm 0.2$ & $46 \pm 1.8$ & $54 \pm 1.8$ & $353 \pm 8$ & $488 \pm 28$ \\
\hline R9 & $405 \pm 20$ & $8.9 \pm 0.3$ & $52 \pm 2.5$ & $48 \pm 2.5$ & $371 \pm 13$ & $542 \pm 37$ \\
\hline R19 & $284 \pm 16$ & $7.2 \pm 0.4$ & $49 \pm 1.5$ & $51 \pm 1.5$ & $529 \pm 8$ & $284 \pm 20$ \\
\hline R25 & $294 \pm 12$ & $8.8 \pm 0.2$ & $42 \pm 2.1$ & $58 \pm 2.1$ & $418 \pm 7$ & $404 \pm 15$ \\
\hline R26 & $266 \pm 7$ & $7.0 \pm 0.3$ & $50 \pm 0.9$ & $50 \pm 0.9$ & $401 \pm 9$ & $334 \pm 12$ \\
\hline R33 & $467 \pm 15$ & $9.9 \pm 0.4$ & $44 \pm 1.0$ & $53 \pm 0.9$ & $459 \pm 7$ & $534 \pm 17$ \\
\hline Rose & $169 \pm 11$ & $5.8 \pm 0.1$ & $44 \pm 0.8$ & $56 \pm 0.8$ & $382 \pm 9$ & $264 \pm 23$ \\
\hline Sin Pepe & $297 \pm 10$ & $8.6 \pm 0.2$ & $53 \pm 4.9$ & $47 \pm 4.9$ & $456 \pm 25$ & $305 \pm 25$ \\
\hline Sirenevy & $355 \pm 0$ & $9.5 \pm 0.0$ & $40 \pm 0.0$ & $60 \pm 0.0$ & $404 \pm 0$ & $525 \pm 0$ \\
\hline Sweet & $272 \pm 19$ & $7.6 \pm 0.3$ & $48 \pm 10.4$ & $52 \pm 10.4$ & $349 \pm 17$ & $428 \pm 104$ \\
\hline Thomson & $280 \pm 32$ & $6.8 \pm 0.4$ & $45 \pm 1.7$ & $55 \pm 0.7$ & $383 \pm 0$ & $412 \pm 66$ \\
\hline Utah Sweet & $124 \pm 16$ & $4.6 \pm 0.3$ & $46 \pm 2.0$ & $54 \pm 2.0$ & $174 \pm 8$ & $359 \pm 42$ \\
\hline Wonderful ${ }_{\mathrm{s}}^{\mathrm{x}}$ & $498 \pm 10$ & $10.0 \pm 0.3$ & $48 \pm 0.7$ & $51 \pm 0.7$ & $387 \pm 5$ & $662 \pm 18$ \\
\hline Wonderful & $355 \pm 49$ & $9.1 \pm 0.5$ & $49 \pm 0.8$ & $51 \pm 0.8$ & $336 \pm 12$ & $553 \pm 95$ \\
\hline Mean & 318 & 8.1 & 49 & 51 & 398 & 424 \\
\hline
\end{tabular}

${ }^{\mathrm{z}}$ Values represent means $\pm \mathrm{SE}$.

${ }^{\mathrm{y}}$ Cultivars: Afganski (R26); Al sirin-nar (R6); Bala Miursal (R25); Barskislatki (C5); Ciparski (C8); Domaci kiseli (C6); Don Sumner North (DSN); Don Sumner South (DSS); Dorosht 5 hahanshahi Khoramabad (I7); Entek habi saveh (I8); Gissarskii Rozovyi (C1); Kaj-acik-anor (R9); Mejhos (R2); Nikitski ranni (R19); Sakerdze (R5); Salavatski (R8); Shirin Pust Ghermez Saveh (I11); and Surh-anor (R33).

${ }^{\mathrm{x}}$ Fruit purchased in a store in Tifton, GA.

CR-400 (8-mm aperture, D65 illuminant) handheld colorimeter (Konica Minolta, Ramsey, NJ) was used to measure the fruit rind and aril color. Three color readings were performed per fruit rind and fruit aril. Color was measured as $\mathrm{L}^{*}, \mathrm{a}^{*}$, and $\mathrm{b}^{*}$. Lightness $\left(\mathrm{L}^{*}\right.$ value) ranged from 0 (white) to 100 (black); $a^{*}$ ranged from $-\mathrm{a}$ (green) to + $\mathrm{a}$ (red); and $\mathrm{b}^{*}$ ranged from $-\mathrm{b}$ (blue) to $+\mathrm{b}$ (yellow). Chroma $\left(\mathrm{C}^{*}\right)\left[\left(\mathrm{a}^{* 2}+\mathrm{b}^{* 2}\right)^{1 / 2}\right]$ and the hue angle $\left(\mathrm{h}^{\circ}\right)$ values $\left(0^{\circ}=\right.$ red-purple; $90^{\circ}=$ yellow; $180^{\circ}=$ blue-green; $270^{\circ}=$ blue $)$ were calculated from the $a^{*}$ and $b^{*}$ values (McGuire, 1992)

Chemical attributes. A juice sample was obtained from each fruit by manually squeezing 50 arils and filtering the juice through two layers of cheesecloth. The soluble solids content (SSC) was measured using a Brixstix digital handheld refractometer (Livermore, CA) that was calibrated with distilled water. Titratable acidity (TA) was determined using an automatic titrator (DL-15; Mettler Toledo, Switzerland) and $500 \mu \mathrm{L}$ of juice diluted with $25 \mathrm{~mL}$ of water. The juice sample was titrated to $\mathrm{pH} 8.2$ using $0.1 \mathrm{M}$ $\mathrm{NaOH}$ after recording the initial $\mathrm{pH}$. Titratable acidity was expressed as the percentage of malic acid present in juice. Total phenols were determined as a measure of the total antioxidant capacity following the FollinCiocalteau method (Singleton et al., 1999), and data were expressed as gallic acid equivalents. The antioxidant capacity was determined by the Trolox equivalent antioxidant capacity (TEAC) and the Cupric reducing antioxidant capacity (CUPRAC) methods (Barros et al., 2007; CastroConcha et al., 2014). The total anthocyanins in juice (dilution 1:5 with water) were calculated from the absorbance at $513 \mathrm{~nm}$ (Kong et al., 2003). 
Statistical design and analysis. The MEANS procedure of SAS (SAS version 9.4; SAS Institute Inc., Cary, NC) was used to perform statistical analyses (mean and $\mathrm{SE}$ ) for all response variables. The CORR procedure was used to calculate the Pearson correlation coefficient of color values in the rind and arils of pomegranate fruit and of antioxidant concentrations and aril color values. The REG procedure was used for the regression of fruit weight as a function of the number of arils per fruit and individual aril weight. Data regarding the years and farms were pooled for statistical analyses.

\section{Results}

Fruit physical attributes. Individual fruit weight showed a wide range from $124 \mathrm{~g}$ for 'Utah Sweet' to $631 \mathrm{~g}$ for 'C1' (Table 2). The fruit diameter ranged from $4.6 \mathrm{~cm}$ for 'Utah Sweet' to $11.3 \mathrm{~cm}$ for ' $\mathrm{C} 1$ '. Fruit weight and diameter were highly correlated $\left(r^{2}=0.818\right.$; $P<0.0001)$. The percentage of weight accounted for by the rind weight (rind fraction) ranged from $30 \%$ for ' $\mathrm{JC}$ ' to $78 \%$ for ' $\mathrm{C} 8$ '. The percentage of fruit weight accounted for by the fresh aril weight (aril fraction) ranged from $22 \%$ for ' $\mathrm{C} 8$ ' to $70 \%$ for ' $\mathrm{JC}$ '. Neither the rind fraction nor the aril fraction was related to fruit weight across cultivars. Individual aril weight ranged from $174 \mathrm{mg}$ for 'Utah Sweet' to $638 \mathrm{mg}$ for 'Cloud'. Across cultivars, individual fruit weight increased linearly with the increasing number of arils, but the fruit weight was unrelated to the individual aril weight (Fig. 1).

Fruit color. Across cultivars, aril color varied from white to deep red. Aril L* values ranged from 15.7 (i.e., dark arils) for 'Crown Jewel' to 46.1 (light arils) for 'Utah Sweet'. The $a^{*}$ value ranged from 0.6 for 'Cloud' (white arils) to 20.5 (red arils) for 'Crab'. The $\mathrm{b}^{*}$ value ranged from 8.7 for 'DJ Forry' to 62.5 for ' $\mathrm{R} 9$ '. The $\mathrm{C}^{*}$ value ranged from 13.4 for 'Cloud' to 24.3 for 'Crab'. The $\mathrm{h}^{\circ}$ value ranged from 29.7 for 'Wonderful ${ }_{\mathrm{s}}$ ' to 87.1 for 'Cloud' (Table 3).

The fruit rind color included green, yellow, pink, and red. The rind $\mathrm{L}^{*}$ value ranged from 39.4 for 'R26' to 55.0 for 'DSN'. The a* value ranged from 7.8 for 'Utah Sweet' to 31.9 for 'Cranberry'. The $b^{*}$ value ranged from 18.2 for 'Crab' to 31.1 for 'R8'. The C* value ranged from 1.0 for 'Rose' to 5.7 for 'Eve'. The $\mathrm{h}^{\circ}$ value ranged from 0.6 for 'Eve' to 7.0 for 'Cloud'.

The color of the rind was related to the color of the arils (Table 4). Aril $L^{*}$ values were negatively correlated with aril $\mathrm{a}^{*}$ values and rind $\mathrm{a}^{*}$ and $\mathrm{C}^{*}$ values, and they were positively correlated with aril $b^{*}$ and $h^{\circ}$ and rind $\mathrm{C}^{*}$ values. Aril a* values were negatively correlated with aril $\mathrm{b}^{*}$ and $\mathrm{h}^{\circ}$ and rind $h^{\circ}$ values, and they were positively correlated with aril $\mathrm{C}^{*}$ and rind $\mathrm{a}^{*}$ and $\mathrm{C}^{*}$ values. Aril $\mathrm{b}^{*}$ values were positively correlated with aril $\mathrm{C}^{*}$ and aril $\mathrm{h}^{\circ}$ values. Aril $\mathrm{C}^{*}$ values were negatively correlated with aril $h^{\circ}$ and rind $h^{\circ}$ values, and they were positively correlated with rind $\mathrm{a}^{*}$ and $\mathrm{C}^{*}$ values. Aril $\mathrm{h}^{\circ}$ values
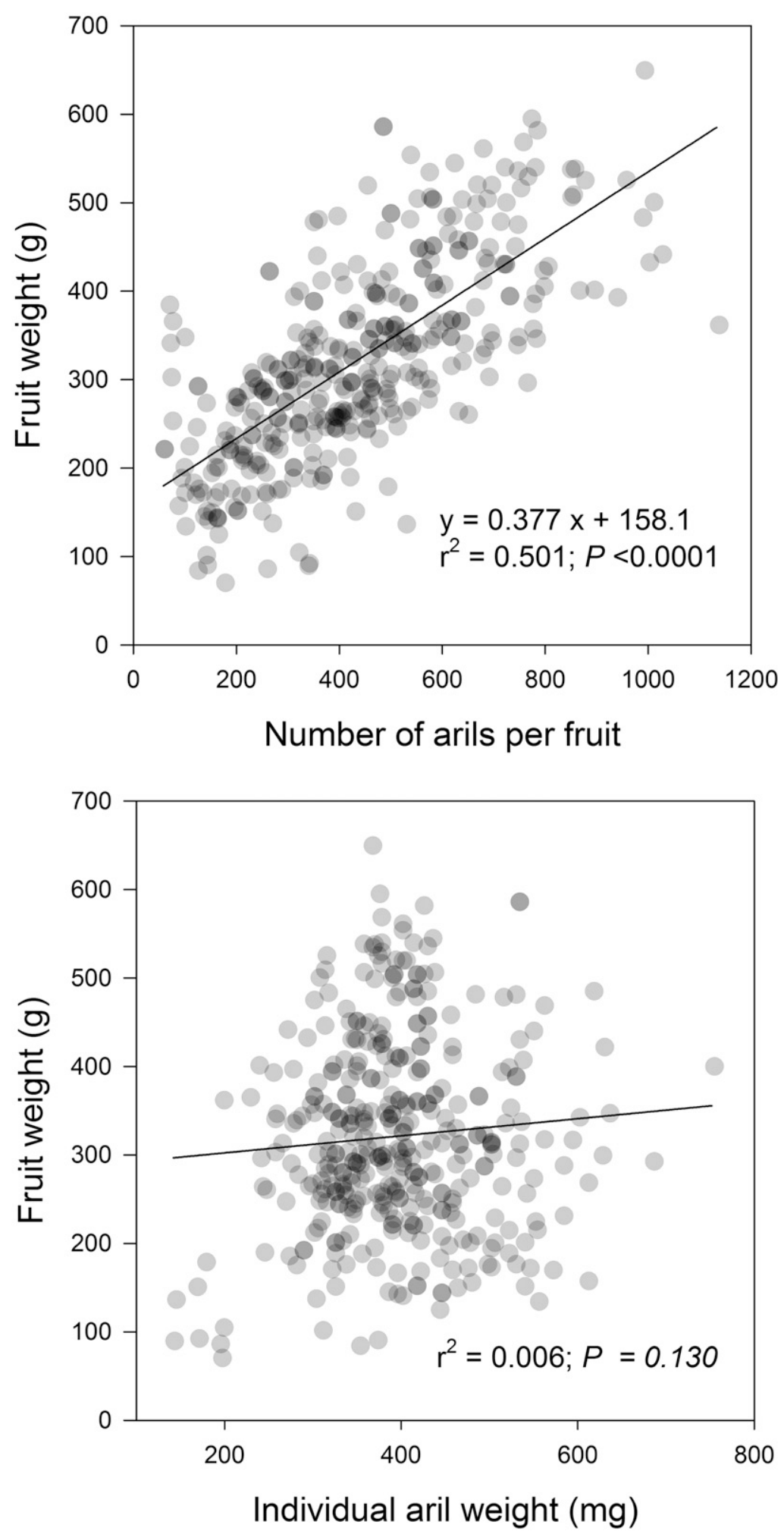

Fig. 1. Relationships between the number of arils and individual aril weight with pomegranate fruit weight for 40 cultivars grown in Georgia. Symbols represent individual fruits.

were negatively correlated with rind $\mathrm{a}^{*}$ and $\mathrm{C}^{*}$ values, and they were positively correlated with rind $\mathrm{h}^{\circ}$ values. Rind $\mathrm{a}^{*}$ values were negatively correlated with rind $\mathrm{h}^{\circ}$ values, and they were negatively correlated with rind $\mathrm{C}^{*}$ values. Rind $b^{*}$ values were positively correlated with $\mathrm{C}^{*}$ and $\mathrm{h}^{\circ}$ values. Rind $\mathrm{C}^{*}$ values were positively correlated with rind $h^{\circ}$ values. The highest correlation coefficient for aril and rind color attributes was for aril $\mathrm{a}^{*}$ and rind $\mathrm{a}^{*}$ values; high $\mathrm{a}^{*}$ values were associated with a red rind and arils.

Fruit chemical attributes. Fruit juice content ranged from $174 \mathrm{mg} \cdot \mathrm{L}^{-1}$ fruit for 'Utah Sweet' to $638 \mathrm{mg} \cdot \mathrm{L}^{-1}$ fruit for 'Cloud' (Table 5). The fruit juice content was positively 


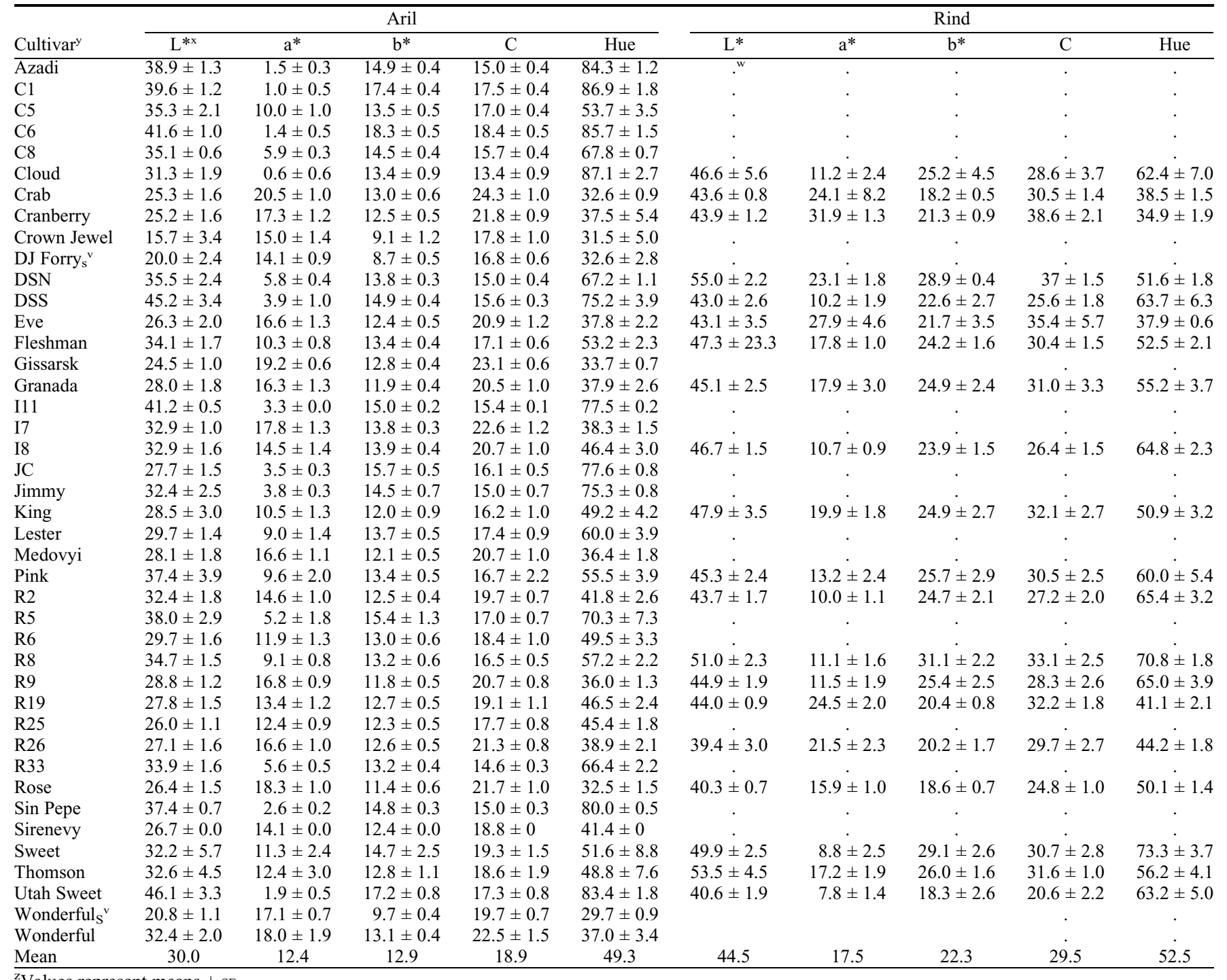

${ }^{\mathrm{z}}$ Values represent means $\pm \mathrm{SE}$.

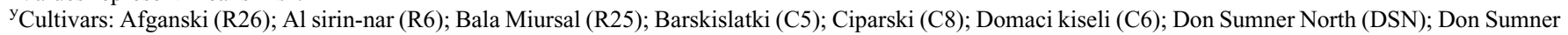
South (DSS); Dorosht 5 hahanshahi Khoramabad (I7); Entek habi saveh (I8); Gissarskii Rozovyi (C1); Kaj-acik-anor (R9); Mejhos (R2); Nikitski ranni (R19); Sakerdze (R5); Salavatski (R8); Shirin Pust Ghermez Saveh (I11); and Surh-anor (R33).

${ }^{x}$ Color $L^{*}$ values ranged from 0 (white) to 100 (black); $a^{*}$ values ranged from $-\mathrm{a}$ (green) to $+\mathrm{a}$ (red); and $\mathrm{b}^{*}$ values ranged from $-\mathrm{b}$ (blue) to $+\mathrm{b}$ (yellow).

w“.” indicates data not collected.

${ }^{v}$ Fruit purchased in a store in Tifton, GA.

correlated with the aril fraction $(R=0.562 ; P<$ $0.001)$ and aril number per fruit $(R=0.208 ; P=$ $0.038)$, but it was not correlated with fruit weight $(R=-0.008 ; P=933)$ or individual aril weight $(R=0.074 ; P=0.467)$.

Cultivars varied from tart to sweet. The fruit SSC ranged from $10.8 \%$ (low sweetness) for 'Sin Pepe' to $16.4 \%$ (high sweetness) for 'Crown Jewel'. The fruit TA ranged from $0.27 \%$ (low acidity) for 'Sin Pepe' to $6.20 \%$ (tart, high acidity) for 'Utah Sweet'. The juice $\mathrm{pH}$ ranged from 2.86 for 'Utah Sweet' to 4.52 for 'Jimmy'. The juice maturity index measured as the SSC/ TA ratio ranged from 1.9 for 'Utah Sweet' to 39.5 for 'Sin Pepe'.

Fruit total phenols and antioxidants. Juice total phenols (measured as gallic acid equivalents) ranged from $463 \mathrm{mg} \cdot \mathrm{L}^{-1}$ for ' $\mathrm{JC}$ ' to $2468 \mathrm{mg} \cdot \mathrm{L}^{-1}$ for 'Wonderful' (grown in Georgia) (Table 6). Juice TEAC values ranged from $10,001 \mu \mathrm{M}$ for 'King' to $59,821 \mu \mathrm{M}$ for
'I11'. Juice CUPRAC values ranged $7471 \mu \mathrm{M}$ for 'Azadi' to 20,576 $\mu \mathrm{M}$ for 'Wonderful' (grown in Georgia). Juice total anthocyanins varied from $1.7 \mathrm{mg} \cdot \mathrm{L}^{-1}$ for ' $\mathrm{R} 19$ ' to 50.0 $\mathrm{mg} \cdot \mathrm{L}^{-1}$ for 'Wonderful' (grown in Georgia).

The correlations among fruit chemical properties, antioxidants, and aril color values are shown in Table 7. Fruit SSC was positively correlated with CUPRAC, total anthocyanins, and aril $\mathrm{a}^{*}$ and $\mathrm{C}^{*}$, and they were negatively correlated with TA, total phenols, and aril $\mathrm{L}^{*}, \mathrm{~b}^{*}$, and $\mathrm{h}^{\circ}$ values. Fruit TA was positively correlated with total phenols and aril $\mathrm{a}^{*}, \mathrm{~b}^{*}$, and $\mathrm{C}^{*}$ values, and it was negatively correlated with CUPRAC and aril $\mathrm{L}^{*}$ and $\mathrm{h}^{\circ}$ values. Total phenols were positively correlated with TEAC, CUPRAC, total anthocyanins, and aril $\mathrm{a}^{*}$ and $\mathrm{C}^{*}$, and they were negatively correlated with aril $\mathrm{L}^{*}$, $b^{*}$, and $h^{\circ}$ values. TEAC was positively correlated with aril $\mathrm{L}^{*}, \mathrm{a}^{*}, \mathrm{~b}^{*}$, and $\mathrm{C}^{*}$ values, and they were negatively correlated with CUPRAC and aril $h^{\circ}$ values. CUPRAC was positively correlated with total anthocyanins and aril $\mathrm{a}^{*}$ and $\mathrm{C}^{*}$ values, and they were negatively correlated with aril $\mathrm{L}^{*}, \mathrm{~b}^{*}$, and $h^{\circ}$ values. Total anthocyanins were not correlated with aril $\mathrm{L}^{*}, \mathrm{a}^{*}, \mathrm{~b}^{*}, \mathrm{C}^{*}$, or $\mathrm{h}^{\circ}$ values.

\section{Discussion}

Physical attributes. Pomegranate is an ancient crop that is grown in many countries, particularly those with a Mediterranean climate (Preece and Moersfelder, 2016). Pomegranate fruit may vary widely in physical and chemical properties (Chater et al., 2018; Radunic et al., 2015). In our study, fruit showed a large variation in fruit weight and fruit color (both rind and arils). Fruit weight differences among cultivars may be attributed to genetics as well as to differences in 
Table 4. Pearson correlation coefficients of color values of arils and rinds of pomegranate fruit from cultivars grown in Georgia.

\begin{tabular}{|c|c|c|c|c|c|c|c|c|}
\hline & Aril a* & Aril b* & Aril C* & Aril $h^{\circ}$ & Rind $a^{*}$ & Rind $b^{*}$ & Rind $C^{*}$ & Rind $h^{\circ}$ \\
\hline \multirow[t]{3}{*}{ Aril L* } & $-0.42214^{z}$ & 0.70534 & -0.06537 & 0.61268 & -0.32250 & 0.11786 & -0.14613 & 0.33479 \\
\hline & $<0.0001^{\mathrm{y}}$ & $<0.0001$ & 0.0985 & $<0.0001$ & $<0.0001$ & 0.0764 & 0.0277 & $<0.0001$ \\
\hline & $640^{x}$ & 640 & 640 & 640 & 227 & 227 & 227 & 227 \\
\hline \multirow[t]{3}{*}{ Aril a* } & & -0.24526 & 0.84761 & -0.90688 & 0.38001 & -0.08161 & 0.22987 & -0.32764 \\
\hline & & $<0.0001$ & $<0.0001$ & $<0.0001$ & $<0.0001$ & 0.2206 & 0.0005 & $<0.0001$ \\
\hline & & 640 & 640 & 640 & 227 & 227 & 227 & 227 \\
\hline \multirow[t]{3}{*}{ Aril b* } & & & 0.27245 & 0.58992 & 0.00578 & 0.11712 & 0.09104 & 0.06418 \\
\hline & & & $<0.0001$ & $<0.0001$ & 0.9309 & 0.0783 & 0.1716 & 0.3358 \\
\hline & & & 640 & 640 & 227 & 227 & 227 & 227 \\
\hline \multirow[t]{3}{*}{ Aril C* } & & & & -0.56459 & 0.34366 & -0.04436 & 0.23310 & -0.27838 \\
\hline & & & & $<0.0001$ & $<0.0001$ & 0.5061 & 0.0004 & $<0.0001$ \\
\hline & & & & 640 & 227 & 227 & 227 & 227 \\
\hline \multirow[t]{3}{*}{ Aril $h^{\circ}$} & & & & & -0.32105 & 0.11137 & -0.15927 & 0.30111 \\
\hline & & & & & $<0.0001$ & 0.0941 & 0.0163 & $<0.0001$ \\
\hline & & & & & 227 & 227 & 227 & 227 \\
\hline \multirow[t]{3}{*}{ Rind $a^{*}$} & & & & & & -0.05664 & 0.66113 & -0.81208 \\
\hline & & & & & & 0.3687 & $<0.0001$ & $<0.0001$ \\
\hline & & & & & & 254 & 254 & 254 \\
\hline \multirow[t]{3}{*}{ Rind $b^{*}$} & & & & & & & 0.69174 & 0.58872 \\
\hline & & & & & & & $<0.0001$ & $<0.0001$ \\
\hline & & & & & & & 254 & 254 \\
\hline \multirow[t]{3}{*}{ Rind $C^{*}$} & & & & & & & & -0.12946 \\
\hline & & & & & & & & 0.0392 \\
\hline & & & & & & & & 254 \\
\hline
\end{tabular}

${ }^{\mathrm{z}}$ Pearson correlation coefficient.

${ }^{\mathrm{y}} P$ value.

${ }^{\mathrm{x}}$ Number of observations.

the time of flower pollination and fruit set. In Georgia, pomegranate cultivars produce various flushes of blooming that start in April and continue to the fall, which can result in variations in fruit size and maturity stage. The time from flowering to fruit maturity in Georgia is $\approx 4$ to 5 months, depending on the cultivar.

The mean fruit size across cultivars at the UGA Tifton Campus Farm (mean, $357 \mathrm{~g}$ ) was similar to that at the Alma commercial farm (mean, $348 \mathrm{~g}$ ) and higher than that at the Ponder Farm (mean, $256 \mathrm{~g}$ ). Reduced fruit size could be at least partially attributed to the nonideal production practices at the University of Georgia farms (e.g., reduced pesticide applications). A study of 'Wonderful' grown in California indicated that the number of arils per fruit was found to be correlated with fruit size, but no relationship was found between individual aril weight and fruit size (Wetzstein et al., 2011). In our study, we found that such a relationship occurs not only for 'Wonderful' but also across a range of cultivars. Wetzstein et al. (2011) proposed that production strategies directed at increasing aril numbers may help to increase pomegranate fruit size.

Chemical attributes. Regarding physical properties, pomegranate fruit showed a wide range of juice yield and chemical properties, such as TA and SSC, resulting in a high range of flavor from very sweet to very acidic. Unexpectedly, 'Utah Sweet' was very acidic in this study, possibly because the fruit was still immature when sampled or because the accession in our collection was more acidic than other accessions of 'Utah Sweet'.

In another study, the 'Wonderful' fruit juice content was found to be $\approx 375 \mathrm{~mL} \cdot \mathrm{kg}^{-1}$ fruit and had a TA of $1.85 \%$ (Chace et al., 1930). In 'Bhagwa' pomegranate, the sugar content, SSC/TA ratio, ascorbic acid, and total anthocyanins increased during fruit maturation, whereas TA, organic acids, and phenolics significantly decreased (Fawole and Opara, 2013b). In 'Ruby' pomegranate, the SSC, sugar (glucose and fructose), and anthocyanin composition increased, whereas TA, organic acids, and total phenolics decreased with advancing maturity (Fawole and Opara, 2013a).

Fruit maturity was not determined in our study; therefore, harvested fruit likely differed in maturity stage among cultivars. Fruit were selected to be visually "mature" or "ready for harvest." Therefore, differences in fruit maturity may have influenced fruit chemical properties. In our study, we sampled fruits over the course of several years to reduce the effects of possible differences in fruit maturity among cultivars on the comparisons of chemical properties among cultivars.

Juice total phenolics (measured as gallic acid equivalents) were among the highest for 'Wonderful' (grown in Georgia) (2468 mg. $\mathrm{L}^{-1}$ ). It is unclear why the majority of cultivars in our study had reduced levels of total phenolics. It is also noteworthy that 'Wonderful' (store) had reduced total phenolics $\left(800 \mathrm{mg} \cdot \mathrm{L}^{-1}\right)$, suggesting that the total phenol concentration of pomegranate may be affected by fruit maturity and production practices as well as by environmental conditions before and after harvest. In Spain, the cultivar Mollar de Elche was found to have total phenols ranging from 2285 to $2457 \mathrm{mg} \cdot \mathrm{L}^{-1}$ (Nuncio-Jáuregui et al., 2015).

In some Tunisian pomegranate cultivars, the total amount of anthocyanin pigmentation of pomegranate juice was found to be largely affected by the cultivar, fruit maturation stage, and geographical location (Gil et al., 1995). In our study, the total anthocyanin concentration varied widely among cultivars, with 'Wonderful' (grown in Georgia) having one of the highest anthocyanin concentra- tions. Monoglucosylated and diglucosylated delphinidins and cyanidins were the major anthocyanins, with cyaniding being more abundant and the delphinidin concentration being increased in cool conditions; in general, anthocyanin accumulation increased with decreasing temperatures during the season (Borochov-Neori et al., 2011).

Studies performed in California showed that as pomegranate fruit mature, TA decreases and SSC increases, resulting in increased sweetness (Chater et al., 2018). In Georgia, however, fruit have high incidences of fruit decay as they mature on the tree. Therefore, early harvesting ( $\geq 1$ weeks before the full maturity stage) may be a strategy to reduce postharvest fruit decay under the conditions in Georgia.

The variability in physical attributes and chemical composition of pomegranate fruit from the cultivars used in the present study may be useful for breeding efforts. Furthermore, it may be of interest to the food industry for the development of different products. Consumers may prefer pomegranate fruit and derived products with a range of colors, acidity, and sweetness.

\section{Literature Cited}

Barros, L., P. Baptista, and I.C.F.R. Ferreira. 2007. Effect of Lactarius piperatus fruiting body maturity stage on antioxidant activity measured by several biochemical assays. Food Chem. Toxicol. 45:1731-1737.

Borochov-Neori, H., S. Judeinstein, M. Harari, I. Bar-Ya'akov, B.S. Patil, S. Lurie, and D. Holland. 2011. Climate effects on anthocyanin accumulation and composition in the pomegranate (Punica granatum L.) fruit arils. J. Agr. Food Chem. 59:5325-5334.

Castro-Concha, L.A., J. Tuyub-Che, A. Moo-Mukul, F.A. Vazquez-Flota, and M.L. Miranda-Ham. 
Table 5. Fruit juice content and juice soluble solids content (SSC), titratable acidity (TA), pH, and maturity index (SSC/TA) of pomegranate fruit of cultivars grown in Georgia. ${ }^{z}$

\begin{tabular}{|c|c|c|c|c|c|}
\hline$\overline{\text { Cultivar }^{\mathrm{y}}}$ & Juice content (mL $\cdot \mathrm{kg}^{-1}$ fruit) & $\mathrm{SSC}(\%)$ & TA (\% malic acid) & $\overline{\mathrm{pH}}$ & Maturity index ${ }^{\mathrm{x}}$ \\
\hline$\overline{\text { Azadi }}$ & $351 \pm 15$ & $12.4 \pm 0.3$ & $0.45 \pm 0.05$ & $3.83 \pm 0.01$ & $27.7 \pm 2.6$ \\
\hline $\mathrm{C} 1$ & $466 \pm 20$ & $14.7 \pm 0.2$ & $1.19 \pm 0.11$ & $3.67 \pm 0.04$ & $12.3 \pm 1.0$ \\
\hline $\mathrm{C} 5$ & $445 \pm 25$ & $14.0 \pm 0.3$ & $0.59 \pm 0.03$ & $3.79 \pm 0.04$ & $23.9 \pm 0.9$ \\
\hline C6 & $360 \pm 26$ & $13.0 \pm 0.4$ & $1.30 \pm 0.07$ & $3.71 \pm 0.02$ & $10.0 \pm 0.7$ \\
\hline $\mathrm{C} 8$ & $433 \pm 34$ & $14.0 \pm 0.2$ & $0.46 \pm 0.02$ & $3.90 \pm 0.03$ & $30.7 \pm 2.3$ \\
\hline Cloud & $638 \pm 1$ & $14.2 \pm 0.1$ & $0.56 \pm 0.04$ & $3.84 \pm 0.15$ & $25.1 \pm 1.9$ \\
\hline Crab & $468 \pm 1$ & $14.0 \pm 0.1$ & $2.60 \pm 0.13$ & $3.45 \pm 0.06$ & $5.4 \pm 0.3$ \\
\hline Cranberry & $523 \pm 27$ & $13.8 \pm 0.1$ & $1.80 \pm 0.12$ & $3.36 \pm 0.05$ & $7.7 \pm 0.5$ \\
\hline Crown Jewel & $393 \pm 31$ & $16.4 \pm 1.5$ & $1.84 \pm 0.17$ & $3.53 \pm 0.05$ & $8.9 \pm 1.7$ \\
\hline DJ Forry $_{\mathrm{s}}{ }^{\mathrm{w}}$ & $310 \pm 10$ & $14.7 \pm 0.3$ & $1.29 \pm 0.20$ & $3.68 \pm 0.04$ & $11.4 \pm 2.2$ \\
\hline DSN & $368 \pm 62$ & $11.9 \pm 0.5$ & $0.62 \pm 0.09$ & $3.52 \pm 0.09$ & $19.1 \pm 3.0$ \\
\hline DSS & $310 \pm 4$ & $12.7 \pm 0.3$ & $1.09 \pm 0.30$ & $3.75 \pm 0.11$ & $11.7 \pm 1.9$ \\
\hline Eve & $508 \pm 1$ & $14.0 \pm 0.2$ & $1.64 \pm 0.07$ & $3.27 \pm 0.06$ & $8.5 \pm 0.4$ \\
\hline Fleshman & $386 \pm 1$ & $14.0 \pm 0.0$ & $0.50 \pm 0.04$ & $3.70 \pm 0.05$ & $28.0 \pm 2.7$ \\
\hline Gissarsk & $414 \pm 28$ & $13.8 \pm 0.2$ & $1.49 \pm 0.13$ & $3.61 \pm 0.03$ & $9.3 \pm 0.8$ \\
\hline Granada & $369 \pm 33$ & $14.6 \pm 0.3$ & $2.11 \pm 0.35$ & $3.53 \pm 0.06$ & $6.9 \pm 1.3$ \\
\hline I7 & $375 \pm 15$ & $14.1 \pm 0.2$ & $1.66 \pm 0.08$ & $3.57 \pm 0.02$ & $8.5 \pm 0.4$ \\
\hline I8 & $325 \pm 26$ & $13.5 \pm 0.1$ & $3.13 \pm 0.13$ & $3.30 \pm 0.04$ & $4.3 \pm 0.3$ \\
\hline I11 & $354 \pm 23$ & $13.8 \pm 0.1$ & $2.33 \pm 0.13$ & $3.62 \pm 0.02$ & $5.9 \pm 0.3$ \\
\hline $\mathrm{JC}$ & $347 \pm 2$ & $12.7 \pm 0.0$ & $1.04 \pm 0.02$ & $4.38 \pm 0.05$ & $12.3 \pm 2.0$ \\
\hline Jimmy & $347 \pm 3$ & $13.8 \pm 0.0$ & $1.48 \pm 0.01$ & $4.52 \pm 0.01$ & $9.3 \pm 0.9$ \\
\hline King & $385 \pm 2$ & $13.9 \pm 0.1$ & $0.61 \pm 0.09$ & $3.70 \pm 0.10$ & $22.6 \pm 5.4$ \\
\hline Lester & $342 \pm 11$ & $13.7 \pm 0.3$ & $0.63 \pm 0.12$ & $3.83 \pm 0.03$ & $21.7 \pm 6.0$ \\
\hline Medovyi & $424 \pm 36$ & $13.8 \pm 0.2$ & $0.46 \pm 0.02$ & $3.77 \pm 0.03$ & $29.9 \pm 1.4$ \\
\hline Pink & $408 \pm 3$ & $11.7 \pm 0.1$ & $0.84 \pm 0.08$ & $3.55 \pm 0.07$ & $14.0 \pm 1.5$ \\
\hline $\mathrm{R} 2$ & $367 \pm 23$ & $13.8 \pm 0.2$ & $2.53 \pm 0.25$ & $3.41 \pm 0.05$ & $5.4 \pm 0.8$ \\
\hline R5 & $406 \pm 23$ & $13.3 \pm 0.5$ & $1.15 \pm 0.16$ & $3.66 \pm 0.02$ & $11.6 \pm 1.3$ \\
\hline R6 & $482 \pm 42$ & $13.8 \pm 0.2$ & $0.65 \pm 0.04$ & $3.30 \pm 0.07$ & $21.3 \pm 1.5$ \\
\hline R8 & $354 \pm 23$ & $13.7 \pm 0.4$ & $2.36 \pm 0.88$ & $3.15 \pm 0.05$ & $5.8 \pm 1.4$ \\
\hline R9 & $371 \pm 30$ & $14.1 \pm 0.5$ & $3.63 \pm 0.82$ & $3.32 \pm 0.08$ & $3.9 \pm 0.6$ \\
\hline R19 & $529 \pm 28$ & $13.8 \pm 0.2$ & $1.20 \pm 0.18$ & $3.47 \pm 0.05$ & $11.5 \pm 3.1$ \\
\hline $\mathrm{R} 25$ & $418 \pm 13$ & $12.9 \pm 0.3$ & $0.70 \pm 0.08$ & $3.31 \pm 0.05$ & $18.5 \pm 2.2$ \\
\hline R26 & $401 \pm 22$ & $13.2 \pm 0.1$ & $1.45 \pm 0.10$ & $3.23 \pm 0.07$ & $9.1 \pm 0.9$ \\
\hline R33 & $459 \pm 6$ & $14.6 \pm 0.2$ & $0.63 \pm 0.08$ & $3.55 \pm 0.03$ & $23.2 \pm 2.8$ \\
\hline Rose & $382 \pm 1$ & $13.9 \pm 0.2$ & $1.32 \pm 0.11$ & $3.75 \pm 0.16$ & $10.5 \pm 1.1$ \\
\hline Sin Pepe & $456 \pm 46$ & $10.8 \pm 0.5$ & $0.27 \pm 0.00$ & $3.55 \pm 0.05$ & $39.5 \pm 1.5$ \\
\hline Sirenevy & $404 \pm 0$ & $11.2 \pm 0.0$ & $0.46 \pm 0.00$ & $3.71 \pm 0.00$ & $24.5 \pm 0.0$ \\
\hline Sweet & $349 \pm 7$ & $13.2 \pm 0.6$ & $1.09 \pm 0.27$ & $3.56 \pm 0.17$ & $12.2 \pm 5.7$ \\
\hline Thomson & $383 \pm 2$ & $14.9 \pm 0.3$ & $1.10 \pm 0.48$ & $3.62 \pm 0.14$ & $13.6 \pm 4.7$ \\
\hline Utah Sweet & $174 \pm 4$ & $12.0 \pm 0.6$ & $6.20 \pm 0.41$ & $2.86 \pm 0.14$ & $1.9 \pm 0.2$ \\
\hline Wonderful & $336 \pm 6$ & $15.23 \pm 0.3$ & $1.23 \pm 0.07$ & $3.78 \pm 0.03$ & $12.5 \pm 0.8$ \\
\hline Wonderful $_{\mathrm{s}}{ }^{\mathrm{w}}$ & $387 \pm 27$ & $15.9 \pm 0.1$ & $1.53 \pm 0.28$ & $3.32 \pm 0.05$ & $10.4 \pm 1.8$ \\
\hline Mean & 398 & 13.7 & 1.41 & 3.59 & 14.5 \\
\hline
\end{tabular}

${ }^{\mathrm{z}}$ Values represent means $\pm \mathrm{SE}$.

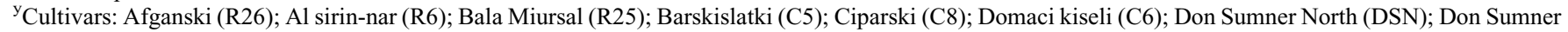

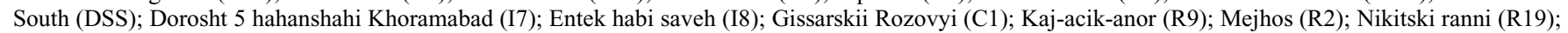
Sakerdze (R5); Salavatski (R8); Shirin Pust Ghermez Saveh (I11); and Surh-anor (R33).

${ }^{\mathrm{x}}$ Maturity index $=\mathrm{SSC} / \mathrm{TA}$ ratio.

${ }^{\mathrm{w}}$ Wonderful $_{\mathrm{s}}$ fruit purchased from a store in Tifton, GA.

2014. Antioxidant capacity and total phenolic content in fruit tissues from accessions of Capsicum chinense Jacq. (Habanero pepper) at different stages of ripening. Scientific World Journal 2014:809073.

Chace, E.M., C.G. Church, and H.D. Poore. 1930. The Wonderful variety of pomegranate: Composition, commercial maturity, and by-products. U.S. Dept. Agr. Circ.

Chater, J.M., D.J. Merhaut, Z.Y. Jia, P.A. Mauk, and J.E. Preece. 2018. Fruit quality traits of ten California-grown pomegranate cultivars harvested over three months. Scientia Hort. 237:1119.

Fawole, O.A. and U.L. Opara. 2013a. Changes in physical properties, chemical and elemental composition and antioxidant capacity of pomegranate (cv. Ruby) fruit at five maturity stages. Scientia Hort. 150:37-46.

Fawole, O.A. and U.L. Opara. 2013b. Effects of maturity status on biochemical content, polyphenol composition and antioxidant capacity of pomegranate fruit arils (cv. 'Bhagwa'). S. Afr. J. Bot. 85:23-31.
Gil, M.I., J. Cherif, N. Ayed, F. Artes, and F.A. Tomasbarberan. 1995. Influence of cultivar, maturity stage and geographical location on the juice pigmentation of Tunisian pomegranates. Z. Lebensm. Unters. Forsch. 201:361-364.

Holland, D., K. Hatib, and I. Bar-Ya'akov. 2009. Pomegranate: Botany, Horticulture, Breeding. Hort. Rev. 35:127-191.

Katz, S.R., R.A. Newman, and E.P. Lansky. 2007. Punica granatum: Heuristic treatment for Diabetes mellitus. J. Med. Food 10:213-217.

Kong, J.M., L.S. Chia, N.K. Goh, T.F. Chia, and R. Brouillard. 2003. Analysis and biological activities of anthocyanins. Phytochemistry 64:923-933.

Matityahu, I., I. Glazer, D. Holland, I. Bar-Ya'akov, R. Ben-Arie, and R. Amir. 2014. Total antioxidative capacity and total phenolic levels in pomegranate husks correlate to several postharvest fruit quality parameters. Food Bioprocess Technol. 7:1938-1949.

McGuire, R.G. 1992. Reporting of objective color measurements. HortScience 27:1254-1255.

Nuncio-Jáuregui, N., M. Cano-Lamadrid, F. Hernández, A.A. Carbonell-Barrachina, and A.
Calín-Sánchez. 2015. Comparison of fresh and commercial pomegranate juices from Mollar de Elche cultivar grown under conventional or organic farming practices. Beverages 1:34-44.

Preece, J.E. and J. Moersfelder. 2016. Pomegranate: The Grainy Apple. J. Amer. Pomol. Soc. 70:187-193.

Radunic, M., M.J. Spika, S.G. Ban, J. Gadze, J.C. Diaz-Perez, and D. MacLean. 2015. Physical and chemical properties of pomegranate fruit accessions from Croatia. Food Chem. 177:53-60.

Singleton, V.L., R. Orthofer, and R.M. LamuelaRaventos. 1999. Analysis of total phenols and other oxidation substrates and antioxidants by means of Folin-Ciocalteu reagent. Methods Enzymol. 299:152-178.

Stover, E. and E.W. Mercure. 2007. The pomegranate: A new look at the fruit of paradise. HortScience 42:1088-1092.

Wetzstein, H.Y., Z. Zhang, N. Ravid, and M.E. Wetzstein. 2011. Characterization of attributes related to fruit size in pomegranate. HortScience 46:908-912. 
Table 6. Pomegranate fruit juice total phenols (measured as gallic acid equivalents), antioxidant capacity [measured as Trolox equivalent antioxidant capacity (TEAC) and Cupric reducing antioxidant capacity (CUPRAC)], and total anthocyanin concentration from pomegranate cultivars grown in Georgia.

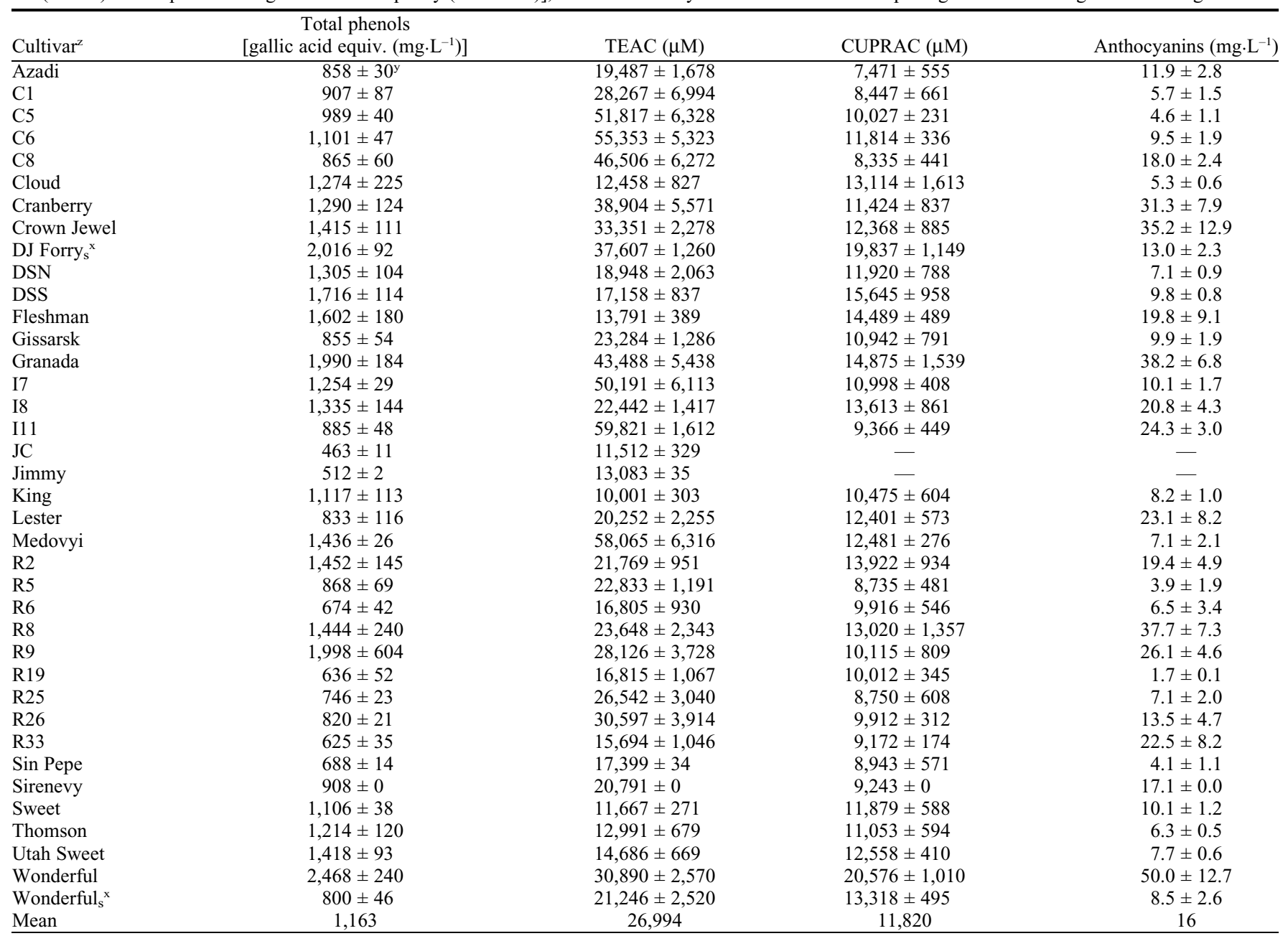

${ }^{\mathrm{z} C u l t i v a r s: ~ A f g a n s k i ~(R 26) ; ~ A l ~ s i r i n-n a r ~(R 6) ; ~ B a l a ~ M i u r s a l ~(R 25) ; ~ B a r s k i s l a t k i ~(C 5) ; ~ C i p a r s k i ~(C 8) ; ~ D o m a c i ~ k i s e l i ~(C 6) ; ~ D o n ~ S u m n e r ~ N o r t h ~(D S N) ; ~ D o n ~ S u m n e r ~}$ South (DSS); Dorosht 5 hahanshahi Khoramabad (I7); Entek habi saveh (I8); Gissarskii Rozovyi (C1); Kaj-acik-anor (R9); Mejhos (R2); Nikitski ranni (R19); Sakerdze (R5); Salavatski (R8); Shirin Pust Ghermez Saveh (I11); and Surh-anor (R33).

${ }^{\mathrm{y}}$ Values represent means $\pm \mathrm{SE}$.

${ }^{\mathrm{x}}$ Fruit purchased in a store in Tifton, GA.

Table 7. Pearson correlation coefficients between pomegranate juice color values $\left(\mathrm{L}^{*}, \mathrm{a}^{*}, \mathrm{~b}^{*}, \mathrm{Chroma}^{*}\right.$, and hue ${ }^{\circ}$ ) with juice total phenols (measured as gallic acid equivalents), antioxidant capacity [measured as Trolox equivalent antioxidant capacity (TEAC) and Cupric reducing antioxidant capacity (CUPRAC)], and total anthocyanin concentrations in fruit from cultivars grown in Georgia.

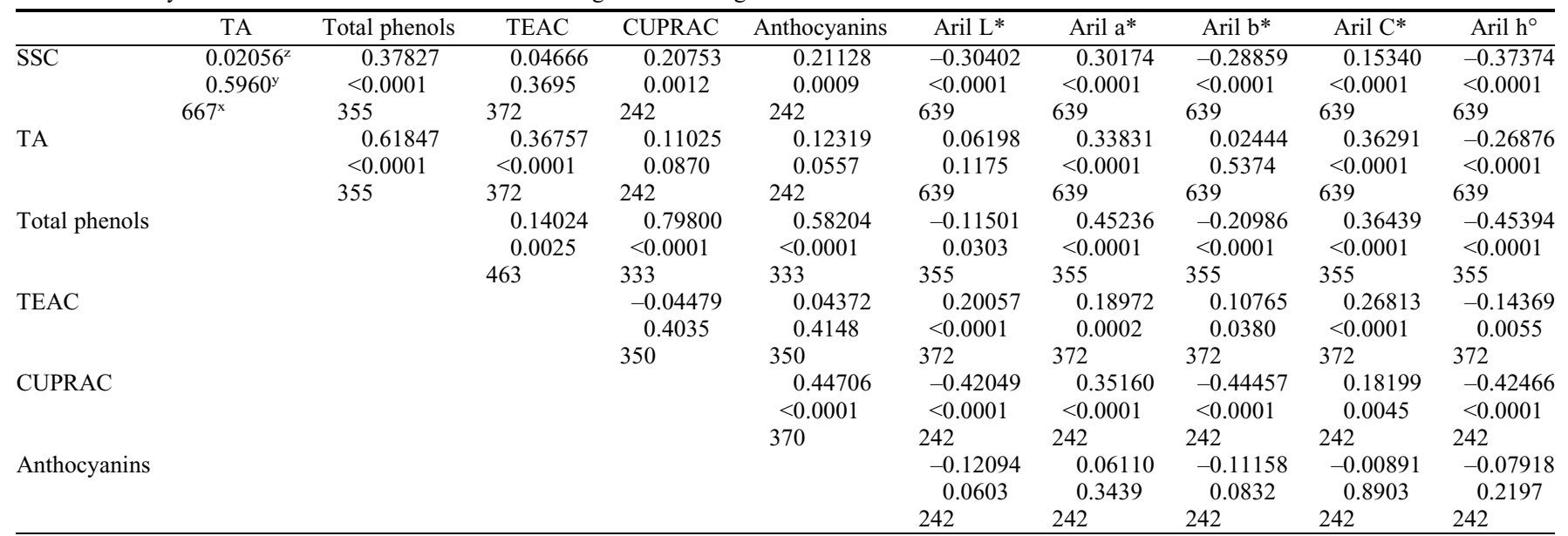

${ }^{\mathrm{z}}$ Pearson correlation coefficient.

${ }^{\mathrm{y}} P$ value.

${ }^{\mathrm{x}}$ Number of observations. 